\title{
Outcome of Primary Discectomy in Lumbar Intervertebral Disc Prolapse
}

\author{
Shahed Anwar Bhuya ${ }^{1 *}$, Shahed Kamal Bhuya ${ }^{2}$, Nasrin Sultana ${ }^{3}$ and Ferdush Jahan ${ }^{4}$ \\ ${ }^{1}$ Department of Ortho-Surgery, Upazila Health Complex, Nangolkot, Cumilla, Bangladesh \\ ${ }^{2}$ Department of Vascular Surgery, National Institute of Cardiovascular Diseases (NICVD), Bangladesh \\ ${ }^{3}$ Department of Radiology and Imaging, Bangladesh Association of Aged \& Institute of Geriatric Medicine (BAAIGM), Dhaka \\ ${ }^{4}$ Department of Microbiology, National Institute of Cardiovascular Diseases (NICVD), Bangladesh
}

Submission: February 20, 2019; Published: February 28, 2019

*Corresponding author: Shahed Anwar Bhuya, Junior Consultant (Ortho-Surgery), Upazila Health Complex, Nangolkot, Cumilla, Bangladesh

Abstract

Purpose: Low back pain secondary to prolapsed lumbar intervertebral disc (PLID) is a major cause of disability. The aim of the study was to see the outcome of primary discectomy in these cases.

Methodology: A total 75 patients were reviewed prospectively and 4 follow up was done till one year after surgery. It was a 3 years study conducted in a private hospital by single surgeon. Radicular pain was observed by visual analogue score and disability status was done by using Oswestry disability index. By using modified Macnab criteria, outcome of the surgery was determined.

Results: Out of 75 PLID patients, male to female ratio was 2.12:1. Mean age of the patients was $36 \pm 8.67$ years. Majority cases of disc involvement was found in L5-S1 level. Radicular pain was significantly $(\mathrm{p}=0.02)$ reduced from preoperative to postoperative status. Disability rate was also reduced from $65 \pm 6$ to $9 \pm 3$ postoperatively $(\mathrm{p}=0.001)$. After one year follow up it was noted that $53.33 \%$ had excellent outcome with only $2.67 \%$ poor outcome and only $5.33 \%$ developed postoperative complications.

Conclusion: Outcome of primary discectomy is satisfactory considering many postoperative findings especially radicular pain and disability Keywords: Primary Discectomy; Prolapsed Lumbar Intervertebral Disc; Outcome

\section{Introduction}

The surgical management of prolapse of a lumbar disc has been practised since Mixter \& Barr [1] discovered the link between sciatica and herniation of a lumbar disc in 1934. Discectomy through fenestration remains the most common approach for this condition in which conservative management has failed. Primary discectomy gives good results, but for revision surgery these results are less certain and the risks greater [24]. Many studies have looked at rates of recurrence which are reported to vary from $3 \%$ to $19 \%$ [3-11]. In this study we have examined the rate of recurrence, and identified the risk factors which would indicate the likelihood of a revision operation being required [11]. The purpose of this study was to explore the outcome of primary discectomy operation in prolapsed lumbar intervertebral disc (PLID) cases.

\section{Methodology}

It was a 3 years prospective interventional study from January 2016 to December 2018 conducted in a private hospital service in Bangladesh. Total 75 prolapse of lumbar intervertebral discs (PLID) was enrolled in the study. A single surgeon has done primary discectomy of all patients with same set up. After operation follow up were done on 6 weeks, 12 weeks, 6 months and 1 year. All records were kept in a semi structured questionnaire. Inclusion criteria for PLID patients were if they complaints of

I. dominant leg pain rather than back pain

II. severe motor and sensory deficits

III. progressive neurological deficits with sciatica

IV. persistent pain hampering daily activities, and

V. restricted straight leg raising test and positive radiographic or magnetic resonance imaging (MRI) findings. Patients of PLID who had spinal instability, other spinal pathology, congenital anomaly, cauda equina syndrome were excluded from the study. In this study only primary cases were included; recurrent cases were not enrolled.

According to the findings of MRI of spinal cord, PLID cases were classified into three categories, 


\section{Orthopedics and Rheumatology Open Access Journal (OROAJ)}

a. Protrusion (focal extension of the posterior margin of the disc beyond the adjacent vertebral bodies).

b. extrusion (presence of disc fragment migrated through a defect of the posterior longitudinal ligament, but still connected to the disc), and

c. sequestration (herniated tissue was no longer connected to the disc) [12]. After selection as a case, patients were made ready for primary discectomy operation. All the pre-requisites for operative procedures and anaesthesia were followed for every patient. At the initiation of operation, a $3.5 \mathrm{~cm}$ midline incision was made at the affected level and to approach the inter- laminar space the para spinal muscles were elevated, and the space was exposed with a Microlumbar retractor. The nerve root was exposed using unilateral flavectomy and retracted medially or laterally according to the disc position. All the loose materials were removed through transverse annulotomy. The midline structures were not handled.

Post operatively, all the patients could mobilise within 24 hours and discharged on about day 7 (range 5-8) and suture were removed on day 14 . All patients underwent 4 follow up sessions on 6 weeks, 12 weeks, 6 months and on 1 year. The variables which were recorded in the present study were pain free interval, side and extent of herniation, operating time, length of hospital stay and pre and post-operative visual analogue score (VAS) for pain. The clinical outcome was evaluated using the modified Macnab Criteria [13].

Result

Table 1: Modified Macnab Criteria13.

\begin{tabular}{|c|c|}
\hline Results & Criteria \\
\hline Excellent & $\begin{array}{c}\text { No pain; no restriction of mobility; return to work and } \\
\text { original level of activity }\end{array}$ \\
\hline Good & Occasional non-radicular pain; return to modified work \\
\hline Fair & $\begin{array}{c}\text { Some improved functional capacity; still handicapped } \\
\text { and unemployed }\end{array}$ \\
\hline Poor & $\begin{array}{c}\text { Continued objective symptoms of root involvement; } \\
\text { additional operative intervention needed at the index } \\
\text { level. }\end{array}$ \\
\hline
\end{tabular}

(Table 1) and the Oswestry Disability Index. Statistical analysis was performed by using SPSS version.23 and all results were expressed by descriptive analysis. For this frequency, percentage were done statistical significance were obtained by $\mathrm{t}$ test. Data were presented as $n=$ number, $\%=$ percentage, ${ }^{*} \mathrm{p}$ value was obtained by independent $\mathrm{t}$ test, ${ }^{* *} \mathrm{p}$ value was obtained by paired $t$ test and $p<0.05$ was considered as significant at $95 \%$ CI Total 75 patients were evaluated in the present study, where male to female ratio was 2.12:1, male predominant. Most of the patients from economically productive age group 15-40 years (61.33\%). Unilateral involvement was more than bilateral and L5-S1 had more than half involvement 57.33\%. Pain score (VAS) reduced from $7.3 \pm 1.9$ to $1.4 \pm 0.4$ one year after surgery. Pain was significantly $(\mathrm{p}=0.02)$ reduced from preoperative status to one year after surgery status. Disability status also reduced from
$65 \pm 6$ to $9 \pm 3$. It was reported that it was significant $(p=0.001)$. In the present study only $5.33 \%$ (4) patients suffered from post operative complications included foot $\operatorname{drop}(n=1)$, dural tear(n=2) and superficial wound infection $(n=1)$. After one year of primary discectomy operation, outcome was satisfactory. Half of the operated patients' outcome (Table 2) was excellent with $38.67 \%$ good and only $2.67 \%$ poor.

Table 2: Clinical profile and surgical outcome with primary discectomy in PLID ( $n=75)$.

\begin{tabular}{|c|c|c|}
\hline Characteristics & n (\%) & p value \\
\hline \multicolumn{3}{|c|}{ Age (Years) } \\
\hline Mean \pm SD & $36 \pm 8.67$ & \\
\hline \multicolumn{3}{|c|}{ Age group } \\
\hline $15-40$ & $46(61.33)$ & \\
\hline $41-60$ & $23(30.67)$ & \\
\hline$>60$ & $6(8)$ & \\
\hline \multicolumn{3}{|c|}{ Gender } \\
\hline Male & $51(68)$ & $0.03^{*}$ \\
\hline Female & $24(32)$ & \\
\hline \multicolumn{3}{|c|}{ Involved Disc level } \\
\hline L2-3 & $2(2.67)$ & \\
\hline L3-4 & $7(9.33)$ & \\
\hline L4-5 & $23(30.67)$ & \\
\hline L5-S1 & $43(57.33)$ & \\
\hline \multicolumn{3}{|c|}{ Involved side } \\
\hline Right & $27(36)$ & \\
\hline Left & $39(52)$ & \\
\hline Bilateral & $9(12)$ & \\
\hline \multicolumn{3}{|c|}{ Postoperative complication } \\
\hline Total & $4(5.33)$ & \\
\hline Dural tear & $2(2.67)$ & \\
\hline Superficial wound infection & $1(1.33)$ & \\
\hline Foot drop & $1(1.33)$ & \\
\hline \multicolumn{3}{|c|}{ Radicular Pain (Visual Analogue score) } \\
\hline Preop & $7.3 \pm 1.9$ & $0.02^{* *}$ \\
\hline Immediate post op & $2.6 \pm 0.7$ & \\
\hline Postop one year & $1.4 \pm 0.4$ & \\
\hline \multicolumn{3}{|c|}{ Disability status (Oswestry Disability Index) } \\
\hline Preop & $65 \pm 6$ & $0.001^{* *}$ \\
\hline Immediate postop & $18 \pm 3$ & \\
\hline Postop one year & $9 \pm 3$ & \\
\hline \multicolumn{3}{|c|}{ Outcome } \\
\hline Excellent & $40(53.33)$ & \\
\hline Good & $29(38.67)$ & \\
\hline Fair & $4(5.33)$ & \\
\hline Poor & $2(2.67)$ & \\
\hline
\end{tabular}

\section{Discussion}

The objectives of this study was to find out the surgical outcome of primary discectomy operation in PLID cases. In this 
study, patients mean age was 36 years with male predominance. Morgan Hough et al. [14] also found similar findings in their study. They reported mean age 39 years with $56.7 \%$ male patients. They also noted $58.2 \%$ cases had L5-S1 and $41.2 \%$ had L4-L5 disc involvement. We have found also most of the cases had L5-S1 involvement. In a study in Bangladesh, Kamrul et al. also found more male patients (73\%) [15]. Kyeng Soo Suk et al. reported in their study that during the primary discectomy procedure, the authors performed partial discectomy of degenerated and fragmented discs, which meant that a relatively smaller amount of disc material was removed from a contained disc than from a no contained disc.

Therefore, most recurrent disc herniation occurred after primary discectomy of a contained disc $(27 / 28,96.4 \%)$. [16] In the present study procedure was almost like them. Here, only $2.67 \%$ cases outcome was poor. Morgan Hough et al. reported $8.7 \%$ cases required further surgery. Here only $5.33 \%$ cases developed postoperative complications like Dural tear, foot drop and superficial wound infection. Kamrul et al. also repoted the similar complications and findings were similar [15]. In the present study it was noted that pain status was significantly reduced from pre-operative status to one year after surgery status $(\mathrm{p}=0.02)$. Kamrul et al. also reported that in their study pain reduced (VAS) from 7.7 to 1.3 after primary discectomy operation [15]. Disability rate was reduced significantly from pre-operative 65 to post-operative $9(\mathrm{p}=0.001)$, the results correspondence with Kamrul et al. report [15].

\section{Conclusion}

It was noted that in prolapsed intervertebral lumbar disc surgical outcome after primary discectomy is quite satisfactory in terms of reduction of pain and disability. Even though surgical treatment yields a satisfactory resolution of symptoms more quickly, the consequences of surgery, in terms of complications, must be carefully considered.

\section{References}

1. Mixter WJ, Barr JS (1934) Rupture of the intervertebral disc with involvement of the spinal canal. N Engl J Med 211: 210-215.
2. Herron L (1994) Recurrent lumbar disc herniation: results of repeat laminectomy and discectomy. J Spinal Disord 7(2): 161-166.

3. Keskimaki L, Seitsalo S, Osterman H, Rissanen P (2000) Reoperations after lumbar disc surgery. Spine 25(12): 1500-1508.

4. Silvers HR, Lewis PJ, Asch HL, Clabeaux DE (1994) Lumbar diskectomy for recurrent disc herniation. J Spinal Disord 7: 408-419.

5. Daneyemez M, Sali A, Kahraman S, Beduk A, Seber N (1999) Outcome analyses in 1072 surgically treated lumbar disc herniations. Minim Invas Neurosurg 42: 63-68.

6. Ito T, Takano Y, Yuasa N (2001) Types of lumbar herniated disc and clinical course. Spine 26(6): 648-651.

7. Lewis PJ, Weir BKA, Broad RW, Grace MG (1987) Long-term prospective study of lumbosacral discectomy. J Neurosurg 67(1): 49-53.

8. Loupasis GA, Stamos K, Katonis PG (1999) Seven to twenty-year outcome of lumbar discectomy. Spine24: 2313-2317.

9. Pappas CT, Harrington T, Sontag VK (1992) Outcome analysis in 654 surgically treated lumbar disc herniations. Neurosurgery 30: 862-866.

10. Weber H (1983) Lumbar disc herniation: a controlled, prospective study with ten years of observation. Spine 8(2): 131-140.

11. Weir BK, Jacobs GA (1980) Reoperation rate following lumbar discectomy: an analysis of 662 lumbar discectomies. Spine 5(4): 366-370.

12. Acharya KN, Nathan TS, Kumar JR, Menon KV (2008) Primary and revision lumbar discectomy: a three-year review from one center. Indian journal of orthopaedics 42(2): 178-181.

13. Macnab IA (1971) Negative disc exploration: an analysis of the causes of nerve-root involvement in sixty-eight patients. JBJS 53(5): 891-903.

14. Primary and revision lumbar discectomy A 16-Year Review from One Centre Cvj Morgan-Hough, PW Jones, SM Eisenstein From Robert Jones and Agnes Hunt Hospital, Oswestry, and Keele University, Keele, England.

15. Kamrul A, Najmus S, Alamgir H, Shahedul IK, Awal MA (2012) Discectomy for primary and recurrent prolapse of lumber intervertebral discs. journal of Orthopaedic Surgery 20(1): 7-10.

16. Suk KS, Lee HM, Moon SH, Kim NH (2001) Recurrent lumbar disc herniation: results of operative management. Spine 26(6): 672-676.

\section{Your next submission with Juniper Publishers} will reach you the below assets

- Quality Editorial service

- Swift Peer Review

- Reprints availability

- E-prints Service

- Manuscript Podcast for convenient understanding

- Global attainment for your research

- Manuscript accessibility in different formats

( Pdf, E-pub, Full Text, Audio)

- Unceasing customer service

Track the below URL for one-step submission https://juniperpublishers.com/online-submission.php 